\title{
Persistence of mucosal abnormality in ulcerative colitis
}

\author{
A. P. DICK, L. P. HOLT ${ }^{1}$, AND E. R. DALTON ${ }^{2}$ \\ From Addenbrooke's Hospital, Cambridge, and the Department of Human Ecology, \\ University of Cambridge
}

EDITORIAL COMMENT It is concluded that in the vast majority of patients with colitis, once the disease has developed, the mucosa remains permanently abnormal whether symptoms are present or not, a fact which may be related to the tendency to relapse and to the increased tendency to carcinoma of the colon.

The mechanism by which mucosal change is produced in ulcerative colitis is obscure. Once an attack of the disease has occurred, there is a tendency for the condition to persist or to relapse, and perhaps correlated with this is the fact that the mucosa may remain abnormal in the absence of active clinical disease. Truelove and Richards (1956) pointed out that more than $50 \%$ of patients in clinical remission had abnormal sigmoidoscopic and histological findings, which could be severe. Dick and Grayson (1961) noted similar findings.

Matts (1961), in a study of the value of rectal biopsy in ulcerative colitis, examined 126 patients. All those who had active (or 'semi-active') disease showed histological abnormality, but in 47 of the patients in whom the disease was quiescent, 37 $(79 \%)$ had an abnormal mucosa histologically. It is not recorded for how long the disease had been quiescent in these patients.

No systematic study to ascertain the proportion of patients in whom the mucosal abnormality persists, and whether a persisting change bears any relation to the duration of freedom from symptoms or the duration of the previous illness, has been reported. It would clearly be of interest and of importance to know how often, once a patient has had an attack of this disease, the colonic mucosa returns to normal, if indeed it ever does.

\section{PRESENT STUDY}

The present investigation has been carried out during the course of a review of 200 cases of ulcerative colitis (to be published), in a proportion of which it has been possible to carry out sigmoidoscopic and histological examination after a minimum

${ }^{1}$ Present address: Department of Experimental Pathology, University of Birmingham.

${ }^{2}$ Present address: Department of Epidemiology and Preventive Medicine, University of Glasgow. period of five years from the onset of the disease. The object has been to ascertain in what proportion of patients mucosal abnormalities persist in the absence of symptoms, to determine whether the presence of abnormalities bears any relation to the duration of previous disease or to the duration of freedom from symptoms, and whether this has any bearing on prognosis.

\section{CLINICAL MATERIAL}

Two hundred patients, first seen by one of us (A.P.D.) between April 1949 and September 1958 have been followed up for a period of between five and 14 years and were reviewed during the latter part of 1963. The series includes 96 patients previously surveyed during 1958 and 1959 (Dick and Grayson, 1961) who have now been followed up for a further period of four years.

The cases were unselected and were all referred to a general hospital serving a mixed rural and urban population and which, for part of the area drained, is the only hospital service available. They were classified according to the extent of the disease into proctosigmoiditis, left-sided, right-sided, and total, and the distribution of the cases is shown in Table I.

TABLE I

TYPE OF CASE

\begin{tabular}{|c|c|c|c|c|c|}
\hline \multirow[t]{2}{*}{ Maximum Extent } & & \multicolumn{4}{|c|}{ Maximum Severity } \\
\hline & & Mild & Moderate & Severe & All \\
\hline \multirow[t]{2}{*}{ Proctosigmoiditis } & $\mathbf{M}$ & 18 & 7 & 1 & 26 \\
\hline & $\mathbf{F}$ & 32 & 22 & 1 & 55 \\
\hline \multirow[t]{2}{*}{ Left-sided colitis } & $\mathbf{M}$ & 3 & 6 & 1 & 10 \\
\hline & $\mathbf{F}$ & 12 & 13 & 1 & 26 \\
\hline \multirow{2}{*}{ Right-sided colitis } & $\mathbf{M}$ & - & - & - & - \\
\hline & $\mathbf{F}$ & 1 & 1 & 1 & 3 \\
\hline \multirow[t]{2}{*}{ Total colitis } & $\mathbf{M}$ & 1 & 8 & 16 & 25 \\
\hline & $\mathbf{F}$ & 4 & 24 & 27 & $55\}$ \\
\hline \multirow[t]{2}{*}{ All } & $\mathbf{M}$ & 22 & 21 & 18 & $61\} 200$ \\
\hline & $\mathbf{F}$ & 49 & 60 & 30 & $139\}$ \\
\hline
\end{tabular}


At the time of this study the state of the patients was as follows:-

Alive

Symptom-free ..........104

Symptoms present.........38

Treated surgically.......22

Dead

Failed follow-up

Total

The outcome and duration of freedom from, or presence or symptoms, in the 200 cases is summarized in Table II.

Of the patients who were interviewed it was possible to perform a sigmoidoscopy and mucosal biopsy in 113, and these subjects form the basis of the present study. Included in the 113 cases are 49 patients in whom a mucosal biopsy had been performed four years previously in an earlier series (Dick and Grayson, 1961).

\section{MUCOSAL ABNORMALITIES}

SIGMOIDOSCOPY Sigmoidoscopic appearances were classified into normal and four grades of abnormality:-

\begin{tabular}{|c|c|}
\hline Grade & Appearance of Mucosa \\
\hline $\begin{array}{l}0 \text { Normal } \\
1 \text { 'Quiescent' }\end{array}$ & $\begin{array}{l}\text { A pink finely granular abnormal mucosa, in } \\
\text { which the vessels were not visible or only } \\
\text { visible in places }\end{array}$ \\
\hline 2 'Slightly active' & $\begin{array}{l}\text { A somewhat reddened, oedematous and } \\
\text { abnormally friable mucosa }\end{array}$ \\
\hline 3 'Very active' & $\begin{array}{l}\text { A very reddened, oedematous and friable } \\
\text { mucosa, often with superficial ulceration and } \\
\text { spontaneous bleeding and/or mucopus in } \\
\text { the bowel lumen }\end{array}$ \\
\hline 4 'Fulminating' & $\begin{array}{l}\text { The flaming red mucosa, often partly covered } \\
\text { with pus, of a fulminating case }\end{array}$ \\
\hline
\end{tabular}

The fallacies and difficulties in interpretation of sigmoidoscopic appearances are well recognized (Baron, Connell, and Lennard-Jones, 1964). In practically every case independent opinions were formed by two observers before an agreed conclusion was reached regarding the grade of abnormality. An obvious difficulty in a survey of this type, which relates the mucosal appearances to clinical findings, is the fact that changes in the mucosa may be more severe higher up the bowel beyond the area seen through the sigmoidoscope.

HISTOLOGY A mucosal biopsy was taken with the instrument previously described by Dick and Grayson (1961). When possible the specimen was obtained from the region of the recto-sigmoid junction or, in some cases, slightly lower down. The three main histological criteria noted were as follows:-

1 Abnormal glandular pattern This was considered as the most important abnormal finding and, in many ways, the feature of greatest interest. The changes include an irregularity in size and shape of the glands, a tendency for them to be larger and to have a larger lumen than normal and an appearance of branching or forking so that the glands may appear more numerous in the deeper than in the superficial layer of the mucosa. The glands appear sparser than in the normal mucosa. Whether exactly similar changes can be found in conditions other than ulcerative colitis is beyond the scope of this paper, but there is no doubt that they are very frequent in colitis. It should be stressed that specimens taken too low down, within an inch or so of the anal canal, may show fewer and rather larger glands than normal and this may be misleading.

2 Excess of chronic inflammatory cells In all cases of active colitis and in many in the quiescent phase, there is an excess of small round cells and plasma cells in the lamina propria and around the glands. This is a much more difficult feature, to assess as the normal range is extremely variable and the finding may be present in various other conditions.

3 Presence of polymorphonuclear leucocytes More than an occasional polymorph is always abnormal, and in acute cases of ulcerative colitis the characteristic feature is the 'crypt abscess' and the presence of acute inflammatory cells in the lamina propria.

Other histological features of colitis are difficult

TABLE II

STATE AT FOLLOW UP

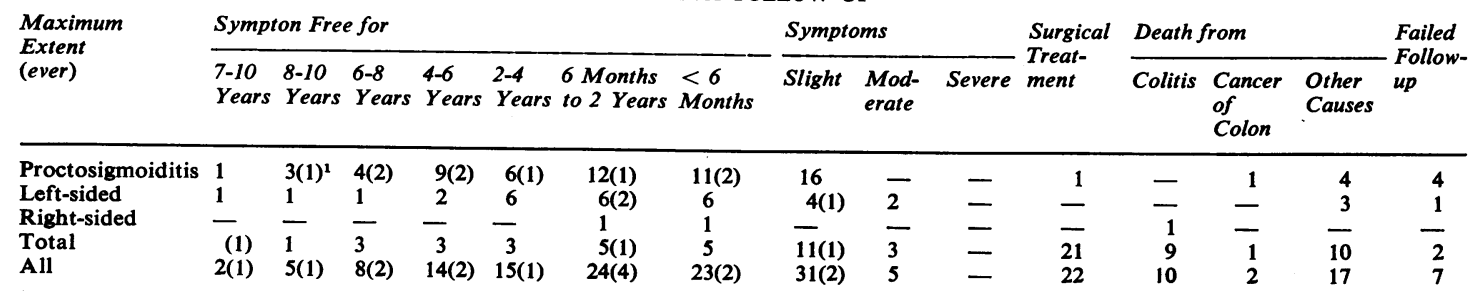

1 Cases where information was obtained only by letter from patient or doctor are shown in brackets. 


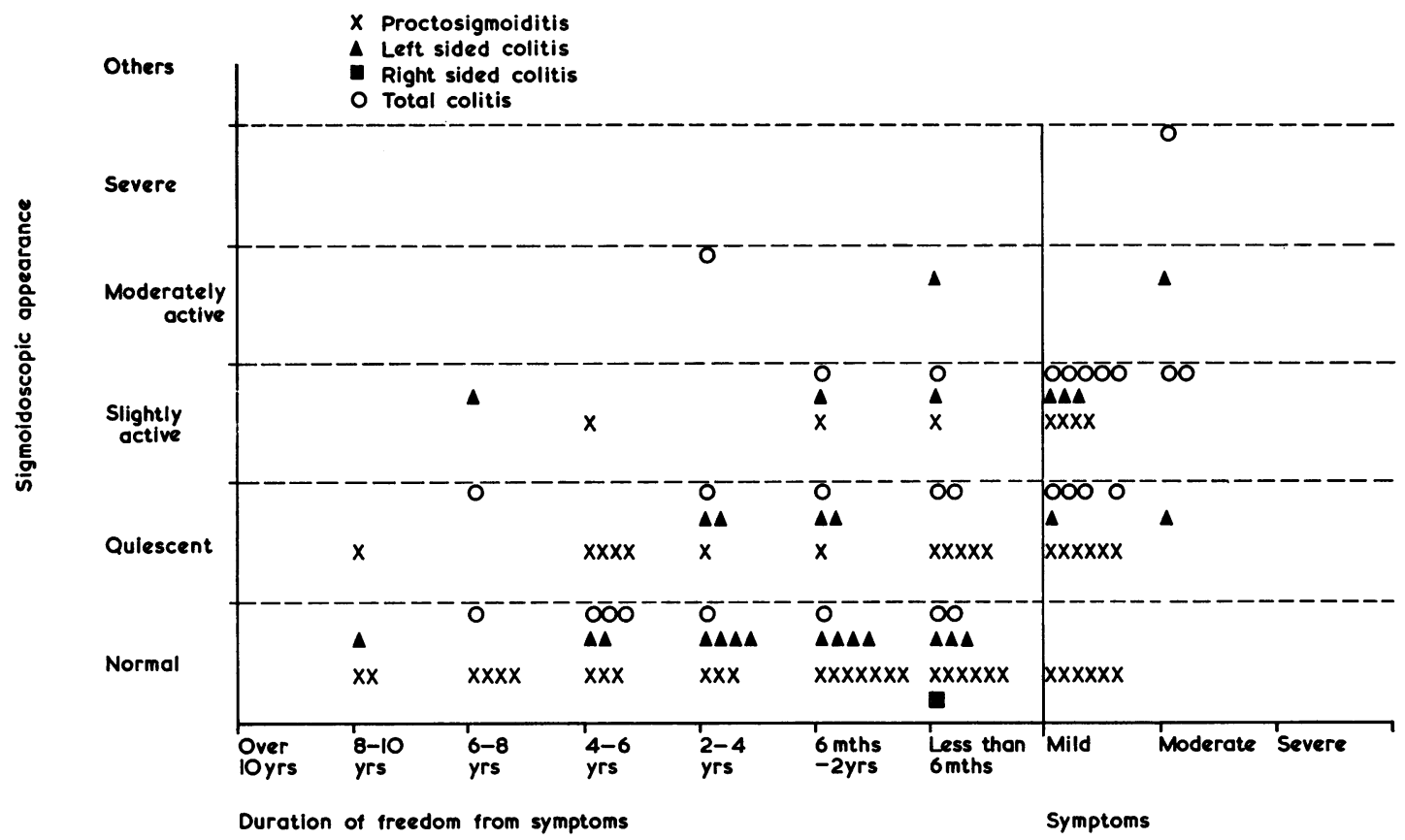

FIG. 1. The presence of symptoms or duration of freedom from symptoms in relation to sigmoidoscopic findings.

to assess in the small specimens obtained by suction biopsy, and the three features given above are considered of most value. Oedema in the lamina propria may be present, but the amount of submucosa is usually insufficient for the estimation of submucosal fibrosis. As a rule, in ulcerative colitis there is a diffuse involvement of that part of the bowel affected, but this is not invariable and sampling error may be responsible for some apparently anomalous findings.

\section{RELATIONSHIP OF CLINICAL STATE AND SIGMOIDOSCOPIC FINDINGS}

The presence and type of symptoms or duration of freedom from symptoms in relation to the sigmoidoscopic findings in the different groups of colitis is illustrated in Figure 1. In the 34 patients who were still having symptoms the sigmoidoscopic appearance was abnormal in all except six. The mucosal appearance may have been abnormal higher up in these six cases, and the histology was abnormal in four in the piece sampled. Conversely, however, and of great interest, as can be seen from Fig. 1, many patients who had been entirely symptom-free for years had an abnormal sigmoidoscopic appearance, and with three exceptions these patients showed abnormal histological findings.
RELATIONSHIP OF CLINICAL STATE AND HISTOLOGICAL FINDINGS

The histological findings in relation to the presence of symptoms and the sigmoidoscopic appearances are set out in Table III. No patient had severe symptoms at the time they were reviewed. As can be seen from Table III, mucosal biopsy was performed in 79 patients who were free of symptoms, and 71 had abnormal histological appearances in the specimen. Of the eight symptom-free patients with normal histology, sigmoidoscopy was also regarded as normal in five, but in three it was considered to be abnormal. Whether histological abnormality would have been found if the biopsy had been taken elsewhere in these eight cases is uncertain. Of 34 patients still having symptoms, the histological appearance of the piece of mucosa obtained was abnormal in 32.

In a disease such as ulcerative colitis it is difficult to determine or assess for what duration symptoms have actually been present, except in those patients who have been under observation during the whole of their illness, or in those who have had only one or two attacks of the disease. In this series patients were classified as having had one attack when symptoms had been present for less than six months. Twentytwo $(11 \%)$ patients fell into this category, and of these 
TABLE III

\begin{tabular}{|c|c|c|c|c|c|c|c|}
\hline \multirow{3}{*}{$\begin{array}{l}\text { Clinical State } \\
\text { Moderate symptoms }\end{array}$} & TATE IN R & RE & TO SIGMO & D & $\mathbf{A P}$ & LF & \\
\hline & \multicolumn{2}{|c|}{ Sigmoidoscopy } & \multicolumn{2}{|l|}{ Histology $y^{1}$} & $\begin{array}{c}\begin{array}{l}\text { Abnormal Glandular } \\
\text { Pattern }\end{array} \\
0\end{array}$ & $\begin{array}{l}\text { Excess of Chronic } \\
\text { Inflammatory Cells } \\
0\end{array}$ & $\begin{array}{l}\text { Presence of Poly- } \\
\text { morphs }\end{array}$ \\
\hline & $\begin{array}{l}\text { Normal } \\
\text { Abnormal }\end{array}$ & $\begin{array}{l}0 \\
5\end{array}$ & $\begin{array}{l}\text { Normal } \\
\text { Abnormal } \\
\text { Normal } \\
\text { Abnormal }\end{array}$ & $\begin{array}{l}0 \\
0 \\
0 \\
5\end{array}$ & $\begin{array}{l}0 \\
0 \\
0 \\
4\end{array}$ & $\begin{array}{l}0 \\
0 \\
0 \\
4\end{array}$ & $\begin{array}{l}0 \\
0 \\
0 \\
1\end{array}$ \\
\hline Mild symptoms & $\begin{array}{l}\text { Normal } \\
\text { Abnormal } 2\end{array}$ & $\begin{array}{r}6 \\
23\end{array}$ & $\begin{array}{l}\text { Normal } \\
\text { Abnormal } \\
\text { Normal } \\
\text { Abnormal 2 }\end{array}$ & $\begin{array}{r}2 \\
4 \\
0 \\
23\end{array}$ & $\begin{array}{r}0 \\
4 \\
0 \\
20\end{array}$ & $\begin{array}{r}0 \\
1 \\
0 \\
17\end{array}$ & $\begin{array}{l}0 \\
0 \\
0 \\
5\end{array}$ \\
\hline $\begin{array}{l}\text { No symptoms for } 6 \\
\text { months or less }\end{array}$ & $\begin{array}{l}\text { Normal } \\
\text { Abnormal } 1\end{array}$ & $\begin{array}{l}12 \\
11\end{array}$ & $\begin{array}{l}\text { Normal } \\
\text { Abnormal } 1 \\
\text { Normal } \\
\text { Abnormal } 1\end{array}$ & $\begin{array}{r}1 \\
11 \\
0 \\
11\end{array}$ & $\begin{array}{r}0 \\
11 \\
0 \\
11\end{array}$ & $\begin{array}{r}0 \\
6 \\
0 \\
11\end{array}$ & $\begin{array}{l}0 \\
0 \\
0 \\
5\end{array}$ \\
\hline $\begin{array}{l}\text { No symptoms for } 6 \\
\text { months to } 2 \text { years }\end{array}$ & $\begin{array}{l}\text { Normal } 1 \\
\text { Abnormal }\end{array}$ & $\begin{array}{r}12 \\
7\end{array}$ & $\begin{array}{l}\text { Normal } \\
\text { Abnormal } 1 \\
\text { Normal } \\
\text { Abnormal }\end{array}$ & $\begin{array}{r}0 \\
12 \\
1 \\
6\end{array}$ & $\begin{array}{r}0 \\
12 \\
0 \\
5\end{array}$ & $\begin{array}{l}0 \\
3 \\
0 \\
4\end{array}$ & $\begin{array}{l}\mathbf{0} \\
\mathbf{0} \\
\mathbf{0} \\
\mathbf{0}\end{array}$ \\
\hline $\begin{array}{l}\text { No symptoms for } \\
2 \text { to } 4 \text { years }\end{array}$ & $\begin{array}{l}\text { Normal } \\
\text { Abnormal }\end{array}$ & $\begin{array}{l}8 \\
5\end{array}$ & $\begin{array}{l}\text { Normal } \\
\text { Abnormal } \\
\text { Normal } \\
\text { Abnormal }\end{array}$ & $\begin{array}{l}0 \\
8 \\
0 \\
5\end{array}$ & $\begin{array}{l}0 \\
6 \\
0 \\
3\end{array}$ & $\begin{array}{l}0 \\
4 \\
0 \\
4\end{array}$ & $\begin{array}{l}0 \\
0 \\
0 \\
1\end{array}$ \\
\hline $\begin{array}{l}\text { No symptoms for } \\
4 \text { to } 6 \text { years }\end{array}$ & $\begin{array}{l}\text { Normal } \\
\text { Abnormal }\end{array}$ & $\begin{array}{l}8 \\
5\end{array}$ & $\begin{array}{l}\text { Normal } \\
\text { Abnormal } \\
\text { Normal } \\
\text { Abnormal }\end{array}$ & $\begin{array}{l}3 \\
5 \\
0 \\
5\end{array}$ & $\begin{array}{l}0 \\
3 \\
0 \\
5\end{array}$ & $\begin{array}{l}0 \\
5 \\
0 \\
2\end{array}$ & $\begin{array}{l}0 \\
0 \\
0 \\
1\end{array}$ \\
\hline $\begin{array}{l}\text { No symptoms for } \\
6 \text { to } 8 \text { years }\end{array}$ & $\begin{array}{l}\text { Normal } \\
\text { Abnormal }\end{array}$ & $\begin{array}{l}5 \\
2\end{array}$ & $\begin{array}{l}\text { Normal } \\
\text { Abnormal } \\
\text { Normal } \\
\text { Abnormal }\end{array}$ & $\begin{array}{l}1 \\
4 \\
2 \\
0\end{array}$ & $\begin{array}{l}0 \\
4 \\
0 \\
0\end{array}$ & $\begin{array}{l}\mathbf{0} \\
\mathbf{3} \\
\mathbf{0} \\
\mathbf{0}\end{array}$ & $\begin{array}{l}\mathbf{0} \\
\mathbf{0} \\
\mathbf{0} \\
\mathbf{0}\end{array}$ \\
\hline $\begin{array}{l}\text { No symptoms for } \\
8 \text { to } 10 \text { years }\end{array}$ & $\begin{array}{l}\text { Normal } \\
\text { Abnormal }\end{array}$ & 3 & $\begin{array}{l}\text { Normal } \\
\text { Abnormal } \\
\text { Normal } \\
\text { Abnormal }\end{array}$ & $\begin{array}{l}0 \\
3 \\
0 \\
1\end{array}$ & $\begin{array}{l}0 \\
3 \\
0 \\
1\end{array}$ & $\begin{array}{l}0 \\
2 \\
0 \\
1\end{array}$ & $\begin{array}{l}\mathbf{0} \\
\mathbf{0} \\
\mathbf{0} \\
\mathbf{0}\end{array}$ \\
\hline
\end{tabular}

${ }^{1}$ No patients who were free of symptoms for over 10 years were biopsed.

three died in the attack; four were treated by ileostomy and colectomy at the time; and three others had died of other causes in the interval. Of the remaining 12, sigmoidoscopy and biopsy were performed in eight. Normal histological findings were present in only two. In one of these two a biopsy performed four years previously had also shown a normal histological appearance. It did not appear, therefore, that this small group, who had had symptoms for less than six months, fared much better in regard to the chances of having a normal mucosa subsequently.

There did not appear to be any relation between the period for which a patient had been symptomfree and the presence or absence of histological change, some of the cases with an abnormal mucosa having been free from symptoms for as long as $\mathbf{1 0}$ years.

FOLLOW-UP OF MUCOSAL BIOPSY CHANGES AFTER FOUR YEARS

In 62 patients a mucosal biopsy had been performed four years previously, in 1959. Of these, 14 then had a normal mucosa and in 48 the histology was abnormal.

In 12 of the 14 patients who had a normal mucosal biopsy in 1959, the examination was repeated. In these the mucosa had become abnormal in nine and was again normal in three. Of the nine patients in whom the histological appearances had become abnormal, three were having slight symptoms and four reported symptoms during the previous two years. There were, however, two patients who would not admit to any symptoms for more than six years, but nevertheless the histological appearances of the biopsy specimens had changed from normal to abnormal. Whether this represented a real change or a difference in the mucosal area sampled is impossible to know. The three patients with normal mucosal histology after the further period of four years had experienced no symptoms during that time.

Of the 48 patients who had an abnormal mucosa previously, 30 were free of symptoms but only eight had remained symptom-free throughout the four years. Four patients had died and two had undergone ileostomy and colectomy. Of the 42 remaining 
patients it was possible to perform a mucosal biopsy in 37. All of these had shown a histologically abnormal mucosa in 1959 and in 36 it was still abnormal in 1963. The one patient in whom the abnormal appearances had apparently become normal had been free of symptoms during the four years. Of the remaining 37 , seven had been entirely free of symptoms during this interval, but 29 reported symptoms to a greater or lesser extent, of whom 11 were still having symptoms at the time of this second survey.

\section{DISCUSSION}

The difficulties of sigmoidoscopic assessment in ulcerative colitis, particularly with minor degrees of abnormality, are well recognized. Attention has been drawn to these difficulties and the degree of observer error by Baron et al. (1964). The giving of enemas or laxatives before sigmoidoscopy may make the interpretation of early changes impossible. Occasional failure of agreement between sigmoidoscopy and histology, when the latter is normal, may be the result of a hyperaemic mucosa, as may occur in other diarrhoeal states not associated with colonic inflammation, being interpreted as colitis. The presence of histological abnormality is less liable to misinterpretation, although whether the abnormality is due to colitis may be more difficult, or impossible, to ascertain.

Truelove and Richards (1956), as already mentioned, pointed out that more than $50 \%$ of patients in clinical remission had abnormal sigmoidoscopic and histological findings which could be severe. They also stated that the histology may be abnormal when the sigmoidoscopic appearances are normal and cited six out of 16 cases in which this was so. Dick and Grayson (1961) found an abnormal histology in nine out of 19 symptom-free patients in whom sigmoidoscopy was normal. On the other hand, Flick, Voegtlin, and Rubin (1962) stated that they found no frankly abnormal biopsy in any patient with a normal mucosa on sigmoidoscopy. They imply a greater accuracy of sigmoidoscopic interpretation and mention that they use 'early criteria'. Conversely, Truelove, and Richards (1956) noted that in nine patients in whom sigmoidoscopy was abnormal, the histology was normal; Dick and Grayson (1961) found one such case and in this survey a further three instances have occurred. This may be due to difficulties of sigmoidoscopic interpretation with minor changes, but when more definite abnormality is present and the histology is normal, sampling error may be responsible.

In this series it was found that about $90 \%$ of patients in clinical remission had an abnormal histological appearance of the mucosa, and the presence or absence of this bore no relation to the duration of freedom from symptoms. It may be in fact that the figure would be higher than $90 \%$ if it were possible to examine the whole colon. Slightly more than half the symptom-free patients had a normal sigmoidoscopic appearance, although the histology in most of these was abnormal. Of the eight patients who had had only one attack of the disease of less than six months' duration in whom biopsy was carried out, the histological findings were normal in only two.

In those 49 patients in whom it was possible to repeat the biopsy after an interval of four years, 36 showed an abnormal mucosa on both occasions, although seven of these had been symptom-free in the interval. One patient's mucosa had apparently become normal, and this patient had been symptomfree in the interval. In 12 who had had a normal biopsy initially it had remained normal in three, but in the other nine had become abnormal, although in two of these patients there had been no further symptoms in the interval.

In this type of study the finding of an abnormal histological appearance on biopsy is evidence of continuing abnormality; the reverse is not necessarily the case, in that changes may be present beyond the reach of the sigmoidoscope or, possibly, sampling error may result in biopsy of a piece of normal mucosa. Of our 200 patients, 29 were dead at the time of survey and 22 alive after surgical treatment. Biopsies were performed in 113 of the remaining 149 patients. One hundred and three of the 113 patients had a histologically abnormal mucosa, including 71 of the 79 symptom-free patients. Allowing that probably more patients than these would have been found to have an abnormal mucosa had it been possible to examine the whole colon, it would seem that the chances of the colonic mucosa of a patient with ulcerative colitis ever returning to normal are small.

From the above evidence it is clear that whatever may be the aetiological factors which determine the onset of colitis, once the patient has had an attack of this condition, it is exceptional for the mucosa to return to normal. The colonic mucosa is renewed every three to five days and so, presumably, some alteration takes place in the key cells at the base of the crypts which results in the production of an abnormal mucosa. Possibly this altered key in the dividing cells bears some relation to the increased tendency to colonic carcinoma, and to the fact that these are sometimes multiple in these patients. It would seem that whatever action the known effective forms of treatment-corticosteroid therapy, sulphasalazine, or possibly an alteration in the psychological 
status of a patient-have in suppressing the more florid manifestations of the disease, this fundamental change in the mucosal cells with the onset of colitis is in most instances permanent. Treatment may suppress the disease and allow enjoyment of full health, although the mucosa remains abnormal and the increased tendency to carcinoma persists.

\section{SUMMARY}

Of an unselected series of 200 cases of ulcerative colitis, followed up for a minimum period of five years, 29 patients were dead and 22 alive after surgical treatment at the time of survey.

Sigmoidoscopy and mucosal biopsy were performed in 113 of the remaining 149 patients, including 49 on whom a biopsy had been performed four years previously. The biopsy showed histological abnormality in 71 of the 79 patients who were free of symptoms, some having been so for many years.
The presence or absence of histological abnormality bore no relation to the duration of freedom from symptoms. In 34 patients who were still having symptoms, the biopsy was abnormal in 32 .

We are much indebted to Dr. L. C. Martin for his advice. We should also like to thank Dr. F. R. Berridge for much radiological advice, Drs. G. A. Gresham and J. H. Rack for histological opinions, and our colleagues at Addenbrooke's Hospital for referring cases of colitis.

\section{REFERENCES}

Baron, J. H., Connell, A. M., and Lennard-Jones, J. E. (1964). Variation between observers in describing mucosal appearances in proctocolitis. Brit. med. J., 1, 89-92.

Dick, A. P., and Grayson, M. J. (1961). Ulcerative colitis: a follow-up investigation with mucosal biopsy studies. Ibid., 1, 160-165.

Flick, A. L., Voegtlin, K. F., and Rubin, C. E. (1962). Clinical experience with suction biopsy of the rectal mucosa. Gastroenterology, 42, 691-705.

Matts, S. G. F. (1961). The value of rectal biopsy in the diagnosis of ulcerative colitis. Quart. J. Med., 30, 393-407.

Truelove, S. C., and Richards, W. C. D. (1956). Biopsy studies in ulcerative colitis. Brit. med. J., 1, 1315-1318. 